Abstracta Iranica Abstracta Iranica

Revue bibliographique pour le domaine irano-aryen

Volume 29 | 2008

Comptes rendus des publications de 2006

\title{
« The maritime trade of Kish during the Mongol period ", in : L. Komaroff, ed., Beyond the Legacy of Genghis Khan. Leiden-Boston, 2006, pp. 51-67.
}

\section{Monik Kervran}

\section{(2) OpenEdition}

\section{Journals}

Édition électronique

URL : http://journals.openedition.org/abstractairanica/27822

DOI : $10.4000 /$ abstractairanica. 27822

ISSN : 1961-960X

Éditeur :

CNRS (UMR 7528 Mondes iraniens et indiens), Éditions de l'IFRI

\section{Édition imprimée}

Date de publication : 15 mai 2008

ISSN : 0240-8910

\section{Référence électronique}

Monik Kervran, « «The maritime trade of Kish during the Mongol period », in : L. Komaroff, ed., Beyond the Legacy of Genghis Khan. Leiden-Boston, 2006, pp. 51-67. », Abstracta Iranica [En ligne], Volume 29 | 2008, document 160, mis en ligne le 15 septembre 2008, consulté le 26 septembre 2020. URL : http:// journals.openedition.org/abstractairanica/27822 ; DOI : https://doi.org/10.4000/abstractairanica. 27822

Ce document a été généré automatiquement le 26 septembre 2020.

Tous droits réservés 
« The maritime trade of Kish during the Mongol period ", in :

L. Komaroff, ed., Beyond the Legacy of Genghis Khan. Leiden-Boston, 2006, pp. 51-67.

Monik Kervran

1 Entrepôt majeur du Golfe Persique dont l'insularité lui permit d'échapper à la tutelle seljuqide, l'île perdit son indépendance face à la puissance montante d'Ormuz quand le gouverneur saghuride du Fars la priva du droit de lever des troupes sur le continent au début du XIII ${ }^{\mathrm{e}}$ siècle. Plus tard aux mains des al-Tibi, puissants marchands que les Mongols appelèrent à leur service, Kish connut au XIII ${ }^{\mathrm{e}}$ s. une prospérité sans précédent (comme en témoignent les sources chinoises) avant d'être absorbée par le royaume d'Ormuz.

2 Synthèse utile et bien documentée sur l'histoire de cette île à laquelle l'E.I. (ancienne et nouvelle édition) ne consacre que quelques lignes.

INDEX

Thèmes : 4.1. Histoire médiévale 
AUTEURS

MONIK KERVRAN

CNRS - Paris 